\title{
Water and Sediment Budget of Casiquiare Channel Linking Orinoco and Amazon Catchments, Venezuela $+$
}

\author{
Alain Laraque ${ }^{1}$, Jose Luis Lopez ${ }^{2}$, Santiago Yepez ${ }^{3, *(1)}$ and Paul Georgescu ${ }^{4}$
}

1 Géosciences Environnement Toulouse-GET (Centre national de la Recherche Scientifique-CNRS, Institut de Recherche pour le Développement-IRD, Université Paul Sabatier-UPS), Observatoire Midi-Pyrénées-OMP, 14 rue Edouard Belin, 31400 Toulouse, France; alain.laraque@ird.fr

2 Instituto de Mecánica de Fluidos, Universidad Central de Venezuela-UCV, Caracas 1050, Venezuela; lopezjoseluis7@gmail.com

3 Departamento Manejo de Bosques y Medio Ambiente, Facultad de Ciencias Forestales, Universidad de Concepción-UdeC, Concepción 407374, Chile

4 Centro de Mecánica de Fluidos y Aplicaciones-CEMFA, Universidad Simón Bolívar-USB, Edificio Fluidos y Operaciones Unitarias, Caracas 89000, Venezuela; pgeorg@cantv.net

* Correspondence: syepez@udec.cl

$+\quad$ This paper was written in tribute to our colleague and friend Paul Georgescu, who passed away shortly before this publication. He supported the development of this work and followed it step by step. As first author, I must thank Paul for inviting me to accompany him in this fantastic adventure in the Casiquiare, carried out in September 2000, in one of the least known and unexplored regions of the planet. Rest in peace, after an exciting existence as an explorer and adventurous scientist, navigating thousands of kilometers of waterways throughout South America.

Received: 4 September 2019; Accepted: 27 September 2019; Published: 3 October 2019

\begin{abstract}
The Casiquiare River is a natural channel that connects two of the greatest rivers in the world, the Orinoco and the Amazon in the South American continent. The aim of this paper is to present a review and synthesis of the hydrological and sedimentological knowledge of the Casiquiare River, including the first hydro-sedimentary balance of the Casiquiare fluvial system conducted 9-12 September 2000 at the bifurcation and mouth during the expedition 'Humboldt-Amazonia 2000 '. Bathymetric flow discharge and physico-chemical measurements were made at the inlet and outlet of the Casiquiare Channel. The main conclusions of this study indicate that Casiquiare is taking a significant proportion of flow (20\% to $30 \%)$ from the Upper Orinoco basin to the Amazon basin. Throughout its $356 \mathrm{~km}$-course, this chameleon channel undergoes significant morphological, hydrological, and bio-geochemical variations between the inlet and outlet, whose most visible witnesses are the increase in its width ( 3 to 4 times), flow ( 7 to 9 times), and its change in water color (white to black water), under the influence of tributaries coming from vast forest plains.
\end{abstract}

Keywords: Casiquiare; Orinoco; Amazon; bifurcation; hydro-sedimentary budget

\section{Introduction}

The Casiquiare River is a geographical rarity and a true hydrological anomaly. It is a natural channel that connects two of the greatest rivers in the world, the Orinoco and the Amazon rivers (Figure 1A). Located on the border between Venezuela and Brazil, the Upper Orinoco deviates part of its waters to the Amazon basin. This is the largest example of river capture in the world. Thus, the same source feeds two different marine estuaries on the Atlantic coast of the South American continent, which makes it unique, taking in consideration the magnitude of the flows transferred from 
the Orinoco River (more than $320 \mathrm{~m}^{3} \cdot \mathrm{s}^{-1}$ ), and the distance between the mouths of the Orinoco and Amazon rivers (about $1500 \mathrm{~km}$ ).
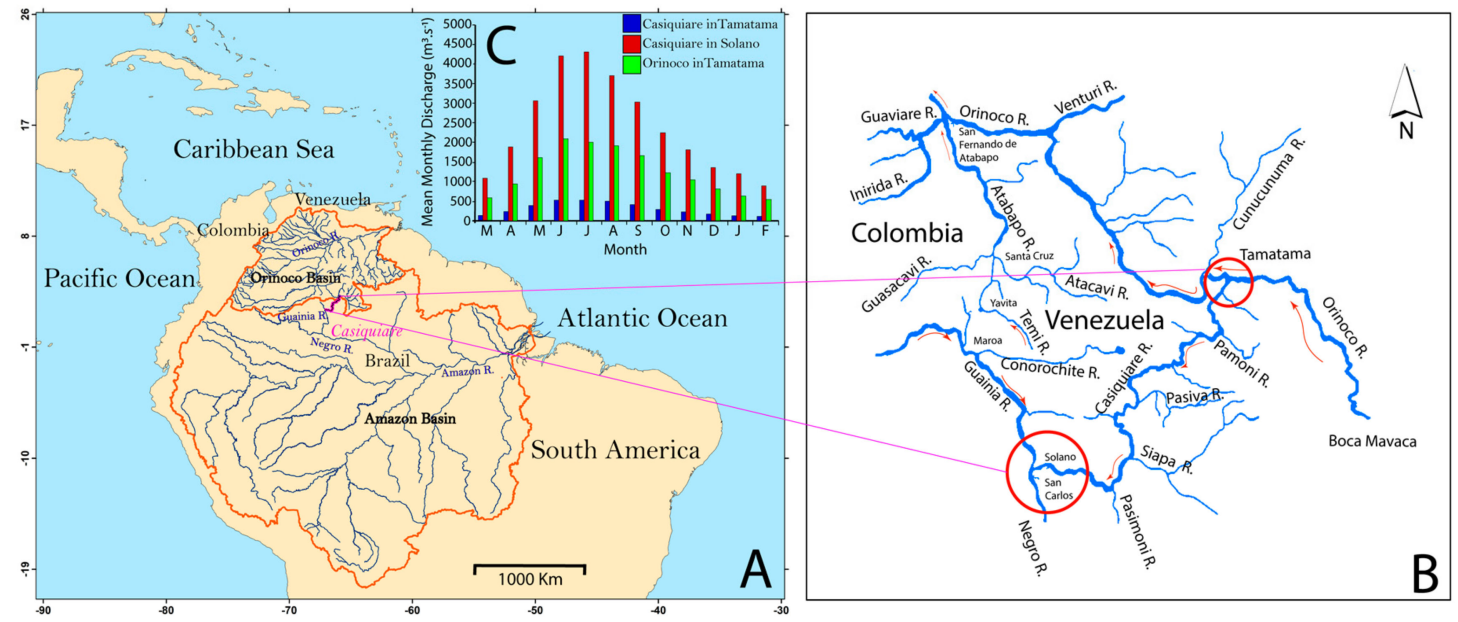

Figure 1. (A) Location map of the Casiquiare natural channel, connecting the Orinoco and Amazon basins. (B) Close view of the fluvial system showing main tributaries of the Casiquiare Channel. (C) Mean hydrographs of the Casiquiare channel (in Tamatama and Solano) and the Orinoco River in Tamatama, using discharge data from the period 1970-1986.

The Casiquiare Channel is a very isolated watercourse (accessible only by river or air), located in an environment virtually devoid of riparian population but subject to some degree of insecurity due to illegal mining activities and guerrilla and paramilitary incursions. For these reasons hydrological measurements have been scarce, the latest being in September 2000 [1] and in December 2001 [2]. Figure 1 presents a close view of the fluvial system. The Upper Orinoco bifurcates downstream at the Tamatama village and runs for about $356 \mathrm{~km}$ before meeting Guainia River, which from this point on becomes the Negro River. The main tributaries of the Casiquiare River are all concentrated along its left bank (Pamoni, Pasiba, Siapa, and Pasimoni rivers) (Figure 1B). Figure 1C presents the mean hydrographs of Casiquiare in Tamatama and Solano, as well as the Orinoco in Tamatama, covering the same period of common discharge data between 1970 and 1986 (from The Global Runoff Data Centre-GRDC website [3]).

This paper aims to present: (a) a review and synthesis of the hydrological and sedimentological knowledge of this unique river; and (b) the first and unpublished hydro-sedimentary balance of the Casiquiare fluvial system at the bifurcation and at the mouth, based on the measurements made by an expedition that took place in September 2000 with the participation of Laraque and Georgescu, two of the authors of this paper [1]. The paper also presents a brief history of the discovery of the Casiquiare Channel and examines various theories concerning its origin. The problem of tracing the boundaries of the Casiquiare basin is also addressed.

\section{Discovery of the Casiquiare Channel}

Spanish conquistadors heard about the existence of the Casiquiare Channel from native people during the seventeenth century. The first account of this hydrologic connection is generally attributed to Acuña in the year 1641 [4]. Sanson Fer, cartographer of the King of Spain, presented a communication between the two rivers on their maps in 1707. Some documents in 1726 refer to trips of Portuguese traders on this channel [5]. Historical sources are also found in Humboldt's narrative [6]. The Jesuit priest Manuel Román, superior of the Spanish missions, registered the existence of a connection between the Orinoco and the Amazon rivers in 1744. The first scientific description of the Casiquiare Channel is attributed to La Condamine [7], but firmly denied at the Academy of Sciences in Paris by Philippe Buarche, the royal geographer, who described Casiquiare as a geographical monstrosity. 
The waterway was not officially referred to by the name of the Casiquiare Channel until 1772 in the so-called "Plan Geográfico de Santa Fe de Bogota, Nuevo Reino de Granada" signed by the cartographer Joseph Aparicio Moreta. However, this is not totally accepted by the scientific community until 1800, when Alexander von Humboldt and Aimé Bonpland landed in Venezuela. They navigated the Casiquiare Channel on 10 May 1800, and closed the controversy over the existence (or not) of a communication between the Amazon and the Orinoco [6]. From this moment, the existence of the Casiquiare Channel has been definitively accepted by the modern science community. Figure 2 shows a map presented by Humboldt indicating the course of the river channel between the Orinoco and Negro rivers [8]. Most recently in 1943, during World War II, the U.S. Army Corps of Engineers carried out the first hydrologic study for the navigability in this channel in order to develop a secure route (away from the German submarines navigating along the South American coast off the mouth of the Amazon) for transportation of latex between Brazil, Colombia, and Venezuela, to be used for war purposes [9].

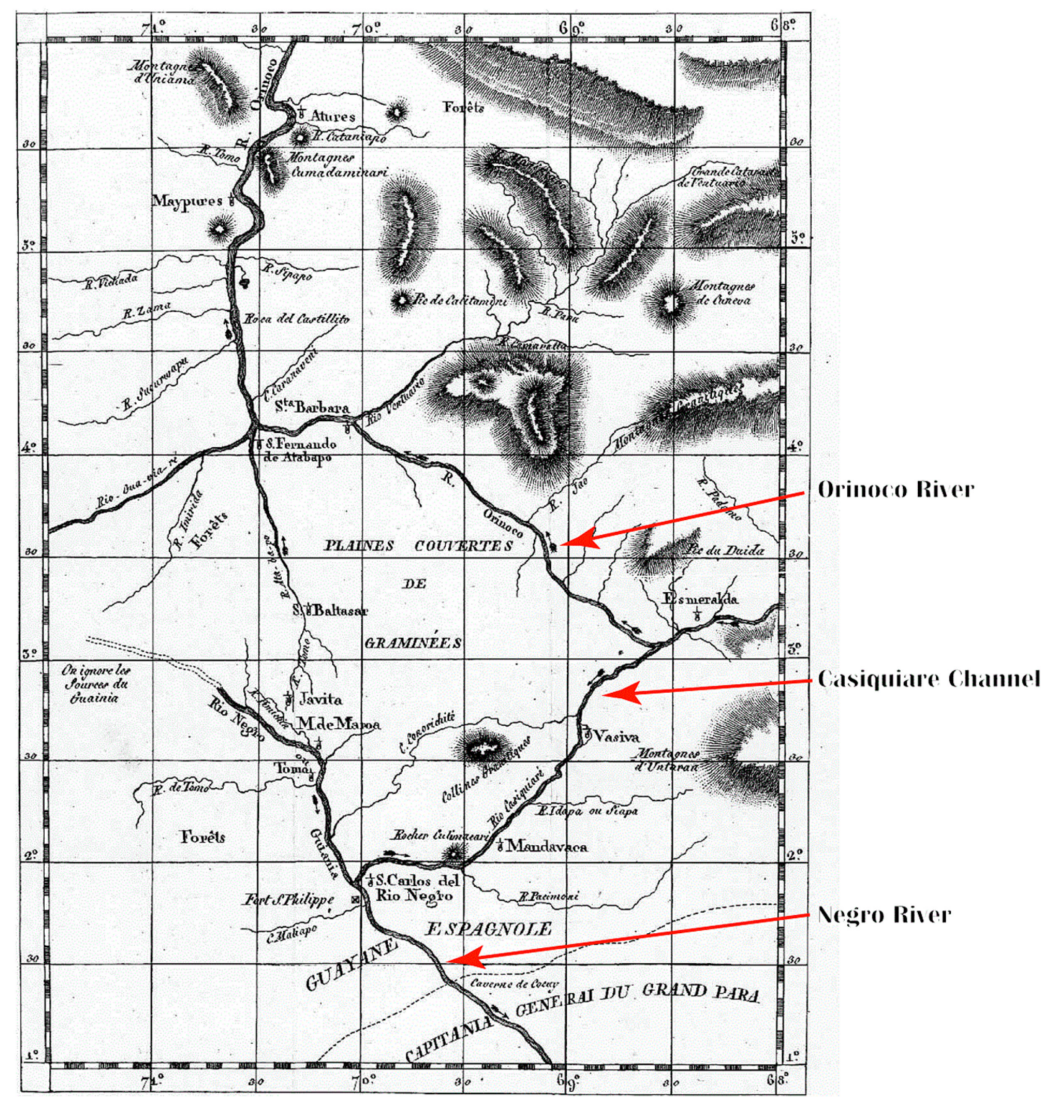

Figure 2. Map presented by Humboldt in 1812 showing the course of the Casiquiare Channel between the bifurcation of the Orinoco and the confluence with the Negro River. Used by permission of Société de Géographie, from Georgescu et al. [10].

\section{General Description}

The description and geographical location of the "hydrological singularity" of the Casiquiare Channel is mentioned in several articles on the hydrology of the Orinoco and Amazon basins $[4,11,12]$. However, scientific knowledge of the Casiquiare Channel is generally limited in time [13-15], subjective, incomplete, approximate, and often erroneous because it results largely from summary observations, without the support of physical measurements. No hydro-sedimentary balance of a complete hydrological cycle has yet been carried out.

Figures 3 and 4 show the morphological differences between the Orinoco bifurcation which coincides with the beginning of the Casiquiare Channel and the confluence of the latter with the 
Guainia River. This bifurcation begins abruptly and perpendicularly to the drainage axis of the Orinoco River (Figure 1B) just downstream of the locality of Tamatama. The Casiquiare Channel turns southwest to meet the Guainia River from the northwest at the end of its stream to form the Negro River, just upstream of San Carlos locality. Further downstream, the Negro River meets Rio Solimões to form the Amazon River near the town of Manaus in Brazil. The coordinates of the bifurcation at its origin, in the Upper Orinoco in Venezuela are N. $03^{\circ} 08^{\prime} 25.26^{\prime \prime}$ and W. $65^{\circ} 52^{\prime} 48.66^{\prime \prime}$, and the coordinates of its mouth, also in Venezuela are N. $02^{\circ} 00^{\prime} 15.18^{\prime \prime}$ and W. $67^{\circ} 06^{\prime} 52.44^{\prime \prime}$.
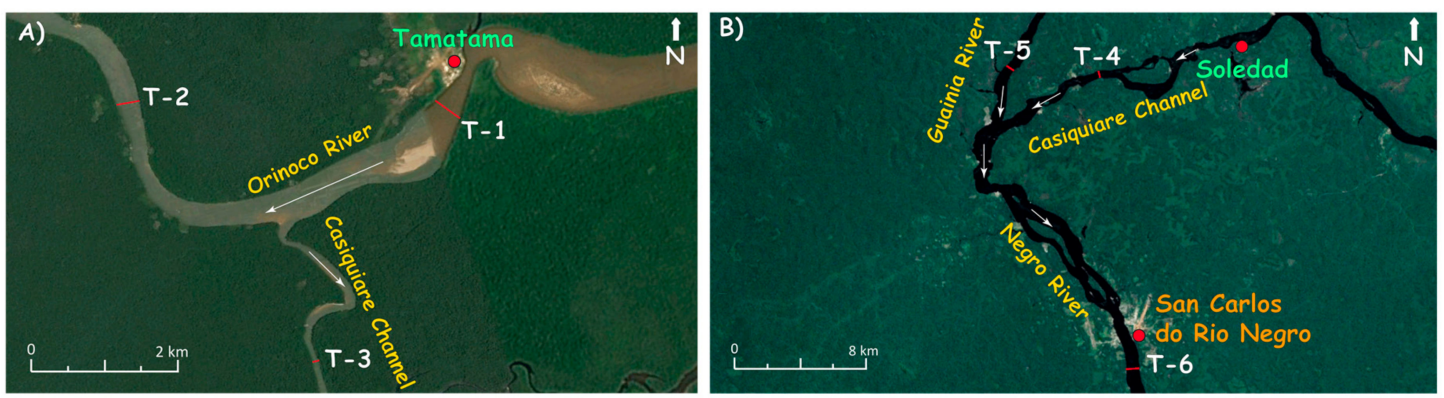

Figure 3. Satellite views of the Casiquiare Channel: (A) at the bifurcation, and (B) at the confluence, showing location of transects T1 to T6 (images from Google Earth).
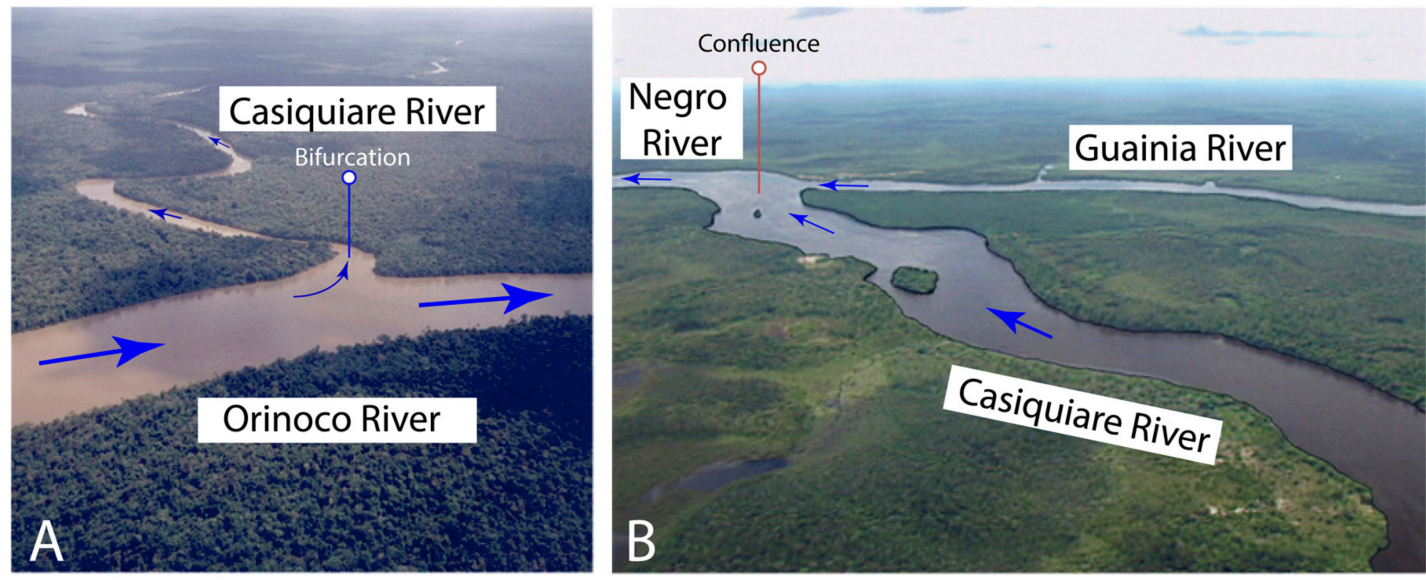

Figure 4. Aerial photos of the bifurcation (A) and confluence (B) taken from a helicopter by A. Laraque on September 10, 2000.

The Casiquiare Channel, bordered by gallery forests, is $356.4 \mathrm{~km}$ long and its width varies from 46 to $610 \mathrm{~m}$. Minimum water depths are about $0.30 \mathrm{~m}$ upstream and $1.2 \mathrm{~m}$ downstream. Between its two extremities, the elevation difference is about $21 \mathrm{~m}$, with an average slope of $6 \mathrm{~cm} \cdot \mathrm{km}^{-1}$ [9]. But this hydraulic gradient can vary from 7.82 to $8.55 \mathrm{~cm} \cdot \mathrm{km}^{-1}$ between low and high water. The surrounding plain has a slope of $10.3 \mathrm{~cm} \cdot \mathrm{km}^{-1}$.

On the Casiquiare left bank, the contribution of the Pamoni, Pasiba, Siapa, and Pasimoni rivers come from the Sierras Curupira, Tapirapeco, Imeri, and Neblina located in southern Venezuela, with peak elevations between 2000 and 3000 m.a.s.l., the highest of which reaches $3014 \mathrm{~m}$ (Pico da Neblina in Brazil). The land drained by the left bank of the Casiquiare and by the Upper Orinoco is composed of undifferentiated Proterozoic rocks [16]. This mountain range with high rainfall rates, about $4000 \mathrm{~mm} \cdot \mathrm{yr}^{-1}$, constitutes a real water reservoir that feeds the left bank of the Casiquiare Channel. This northwest-facing runoff reflects the slight slope in the same direction, which drains the plains surrounding the Guyanese shield between 150 and 200 m.a.s.l., where some steep residual landforms are observed at about 500 m.a.s.l. [14]. 


\section{Origin and Evolution of the Casiquiare Channel}

Geologists agree that the capture of the Orinoco by the Casiquiare River is more recent than the formation of the Andean range which has profoundly modified the direction of circulation of the Amazon and Orinoco rivers. According to ichthyological observations, Goldstein, [17] attributes the birth of the Casiquiare Channel to the capture of a secondary channel of the Orinoco River on the Pleistocene-Holocene limit, about 10,000 years ago.

Stern [18] was the first one to describe the genesis of the Casiquiare. Vareschi [19] mentioned an incomplete capture by overflow and regressive erosion produced by a northern affluent of the Negro River. This is one of the largest examples of natural hydrological capture in the world. The mechanism of capture, the current situation, and future trends are illustrated in Figure $5[18,19]$. At remote times the Casiquiare did not exist. The Orinoco River passed in two channels around a fluvial island denoted by I (Figure 5-1). The Upper Casiquiare used to be a branch of the Orinoco River. The confluence of the Cunucunuma River $(\mathrm{CU})$ with the Orinoco $(\mathrm{O})$ was located at the north branch $(\mathrm{S})$ of the island. The lower reach of the south branch was Caño Seco (CS), which used to flow around Quiritari island (Q) before entering the main channel $(\mathrm{O})$ of the Orinoco River. At some distance to the south, the Pamoni River, a perennial river, was the headwaters of the river today called Casiquiare, which flowed into the Negro River and the Amazon basin. The approximate drainage division between the Orinoco and Amazon basins used to be the dashed line denoted by D (Figure 5-1).
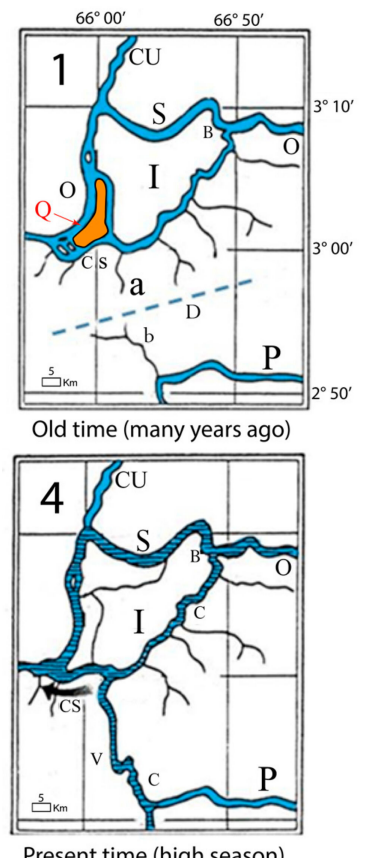

Present time (high season)

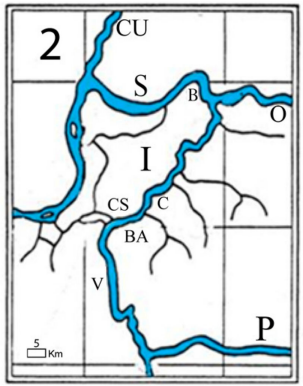

Present time (normal water)

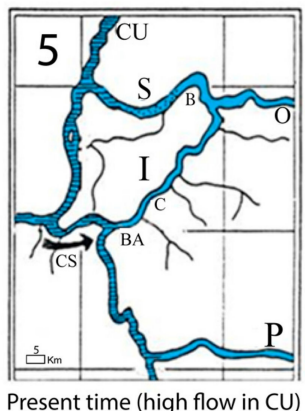

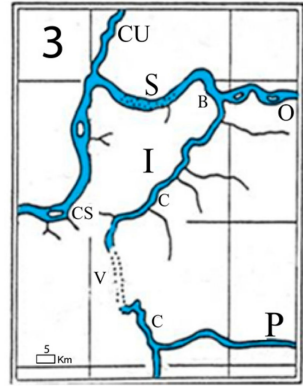

Present time (dry season)

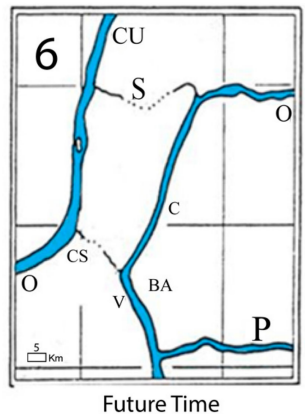

Figure 5. Sketch-maps of the Casiquiare fluvial system showing past and future trends in the evolution of the channel, according to Stern [18] as illustrated by Vareschi [19]. O = Orinoco; C = Casiquiare; CU = Cunucunuma River; $\mathrm{B}=$ bifurcation; $\mathrm{I}=$ fluvial island; $\mathrm{CS}=\mathrm{Caño} \mathrm{Seco;} \mathrm{BA}=$ Buenos Aires sector; $\mathrm{V}$ = Venados (abandoned town); $\mathrm{P}=$ Pamoni River; $\mathrm{S}=$ north channel of the island; $\mathrm{Q}=$ Quiritari Island (in orange); $\mathrm{D}=$ water divide; $\mathrm{a}=$ small channel; $\mathrm{b}=$ small channel.

Probably, during high flows, the south branch of the Orinoco River began flowing to the Pamoni River through channel (a) and channel (b). The alluvial material composing the drainage divide (D) was eroded and a new channel was formed, which was the genesis of the Casiquiare River by avulsion processes. The capture of the Orinoco waters was helped by the existence of a terrain slope larger toward the south than toward the west. Caño Seco was abandoned and became a dry channel, which flows only during the high flow season. Near an abandoned town, called Venados site (V), the Casiquiare is almost dry during the low season, making navigation difficult (Figure 5-3). This 
observation was made during the Oriampla Expedition to the Orinoco in January 1980 [10]. At present time, during a combination of high flows in the Cunucunuma River and low flows in the Orinoco, the flow in Caño Seco (CS) could revert as it is shown in Figure 5-5.

Stern [18] reported that the flow discharge, flow depth and width in the upstream reach of the Casiquiare Channel had increased in the last 50 years, according to stories from old pilots, navigators, and local inhabitants. This is reinforced by the accumulation of sediment and point bars in the Orinoco River downstream from the point of bifurcation. Stern suggested that in a future time the Casiquiare will totally capture the Orinoco flows and that the headwaters of the Orinoco would be the headwaters of the Cunucunuma River (Figure 1B). Although a few authors like [20] questioned the Stern theory of the Casiquiare formation, Vareschi [19] supports the opinion of Stern based on field observation of two abandoned channels connecting the Orinoco with the Casiquiare, noting that their channel widths were significantly smaller than the Casiquiare width at the present time.

Using a geomorphometric analysis of the region with Digital Elevation Models, Hypsometry, Isobases and Swath Profiles, Grohmann et al. [21] explain the capture of the Orinoco River and the formation of Casiquiare canal by tectonic controls.

A recent study by Stokes at al. [22] used measurements from the 1943 U.S. Army Corps of Engineers and hydraulic calculations to show that the Rio Casiquiare is actively capturing the Upper Orinoco River, driven by a combination of in-channel sedimentation in the Orinoco and seasonal inundation of the drainage divide that favors the steeper Casiquiare River. They consider that the ongoing reorganization of the river system, is under tectonic controls and also conclude that the Casiquiare River course will eventually become the dominant channel, which confirms Stern's pioneering studies [18,23].

To conclude this paragraph, it seems necessary to clarify that the location of the initial capture of the Orinoco is located at the level of the south branch and downstream of the river island "I" in Figure 5-1-5, and not at the bifurcation of the Casiquiare, which is located upstream of the same river island and downstream of Tamatama, as is too often mentioned in the literature. Indeed, at this point in past time, it was a simple division of the Orinoco River into two branches that bypassed the river island "I". The critical area of the initial avulsion that diverted the south branch of the Orinoco is located at Caño Seco (Figure 5-1-5). Subsequently, in the event of a continuation of this river capture, the northern branch of the Orinoco, which bypasses the river island, will dry up and so will the Caño Seco. At that time the capture will be total and the upper Orinoco River will be completely diverted towards the Amazon basin (Figure 5-6).

\section{Data and Methodology}

\subsection{Sampling and Measurements}

During the September 2000 expedition, bathymetric, discharge and physico-chemical profile measurements were made along six transects denoted by T1 to T6 (Figures 3 and 6), using a small boat provided with an echo-probe (Eagle Strata 128) coupled with a GPS (GARMIN, Etrex model; Ap = +/$1 \mathrm{~m}$ ), a turbidimeter (AQUALITYC; $\mathrm{Ap}=+/-0.01 \mathrm{NTU}$ ), a thermometer, a portable $\mathrm{pH}$ meter (WTW $\mathrm{pH}$ $320 ;+/-0.01$ ), and a conductivity meter (WTW LF 318; Ap $=+/-0.1 \mu \mathrm{S} \cdot \mathrm{cm}^{-1}$ ). The physico-chemical measurements were made at three points on the vertical (surface, middle, and bottom) at the center of the river. Total suspended sediment (TSS) was also collected with a $500 \mathrm{~mL}$ sampler. For discharge measurement, first, a bathymetric survey is carried out using the echo sounder and GPS to obtain the flow area at each respective section of the river. The flow velocity is determined using the boat (canoe) as a drifting float on three longitudinal lines distributed at $25 \%, 50 \%$, and $75 \%$ of the bank distance of the section. GPS provides us the drift speed of the canoe, and therefore the surface velocity. Thus, the average velocity of the flow section is calculated by applying a correction coefficient between 0.8 and 0.95 [24], generally accepted for this type of flat watercourse. Water discharge was determined as the product of the velocity and the area, and material flows (in $\mathrm{kg} \cdot \mathrm{s}^{-1}$ ) were obtained by multiplying the average values of the measured TSS concentrations (in $\mathrm{mg} \cdot \mathrm{L}^{-1}$ ) with the discharge (in $\mathrm{m}^{3} \cdot \mathrm{s}^{-1}$ ). 


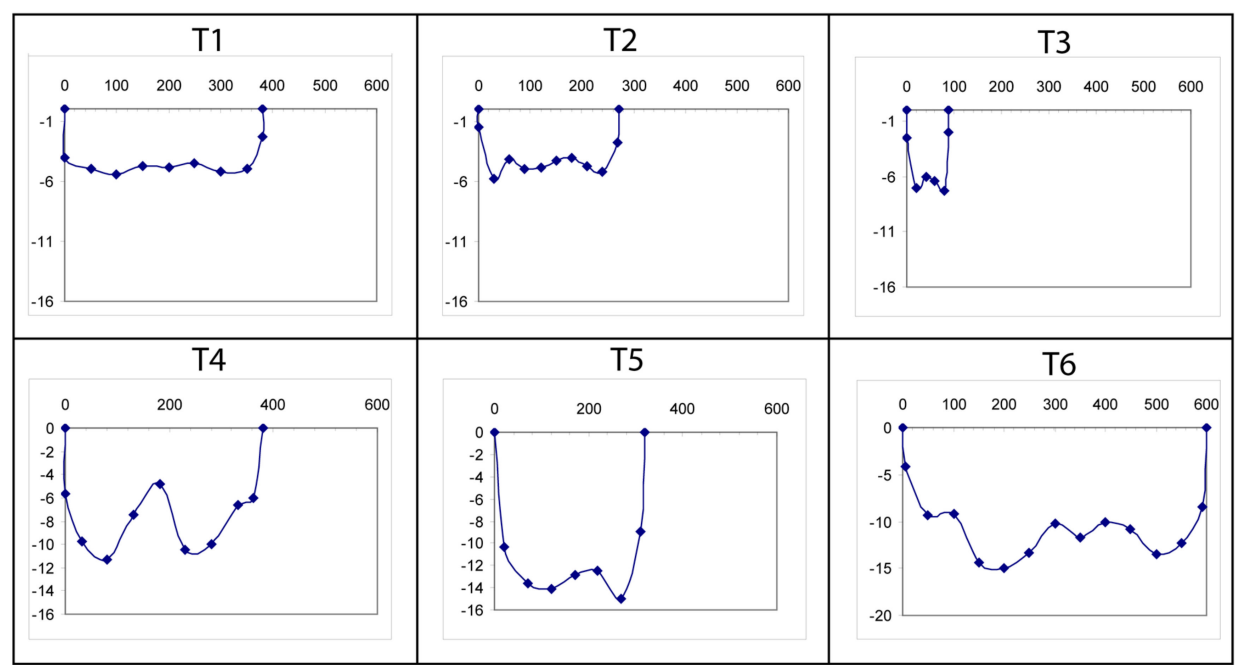

Figure 6. Bathymetric profiles obtained at 6 different sections in the bifurcation and in the confluence of the Casiquiare Channel. T1: Orinoco upstream of bifurcation; T2: Orinoco downstream of bifurcation; T3: Casiquiare at inlet; T4: Guainia River before confluence; T5: Casiquiare at outlet; T6: Negro River at San Carlos. Depths and widths are given in meters. See Figure 3 for location of cross sections collected in the 2000 expedition.

\subsection{Analytical Techniques}

Water samples were filtered with filters of acetate (cellulose) with a porosity of $0.45 \mu \mathrm{m}$ for the total suspended sediment (TSS). After being dried, these fractions were weighed to a precision of 0.1 $\mathrm{mg}$ (Sartorius scale). In the laboratory, $100 \mathrm{~mL}$ of filtrates were heated in a steamer at $105^{\circ} \mathrm{C}$ to obtain the dry residue, which corresponds to the sum of total dissolved solids (TDS) and the total dissolved organic matter (DOM).

\subsection{Morphometric Analysis}

A morphometric analysis was carried out to accurately check the contributing area of each basin, including a description of the elevation and slope changes both of the Upper Orinoco basin and the Casiquiare Canal basin. For this, we used the SRTM (Shuttle Radar Topography Mission)—Digital Elevation Model (DEM) of the Nasa at 1 arc of a second, with approximately $30 \mathrm{~m}$ [25] in combination with the Fluvial Corridor Toolbox software [26]. Thus, a synoptic diagram was created for each basin. From this set of digital cartographic data in three coordinates (XYZ) or DEM, "elevation and slope tool" (in Fluvial Corridor Toolbox) enables the extraction of topographical data such as the elevation and the slope of a set of polylines (e.g., a hydrographic network). It is based on the add surface information (3D Analyst Tools) and can be applied over a linear network. The "Z-mean" elevation was calculated over the entire segment. Finally, the "slope" field is the ratio between the upstream and downstream difference of elevation and the segment length. The drained area at the points is also important information for the dynamics of the river system. Therefore, the "watershed tool" was also used to determine the drainage area along a continuum. It is based on the extraction of data included in a flow accumulation raster, provided by the user and derived from a DEM [26].

\section{Results}

The hydrologic data (maximum depth, width of section, and surface stream velocity) and physical-chemical parameters $\left(\mathrm{T}^{\circ}\right.$, electrical conductivity, $\mathrm{pH}$, turbidity, and suspended sediment concentration) are presented in Table 1 for each section in consideration. Figure 6 presents the bathymetric profiles at the three cross sections of the Orinoco-Casiquiare's bifurcation and at the three cross sections of its confluence with the Guainia River to form the Negro River. Comparisons of these data and calculations of hydro-sedimentary budgets at the three measuring points of the bifurcation and confluence of the Casiquiare Channel provide a better understanding of its hydro-geodynamic functioning. 
Table 1. Hydrologic and physico-chemical data obtained from measurements at the bifurcation and confluence of the Casiquiare Channel in September 2000. Q = flow discharge; $\mathrm{V}=$ surface flow velocity; $\mathrm{W}$ max = maximum channel width; $\mathrm{H}$ max = maximum depth; Temp. = temperature; EC = electrical conductivity; Turb = turbidity; TSS = total suspended sediment concentration.

\begin{tabular}{|c|c|c|c|c|c|c|c|c|c|c|c|c|c|c|}
\hline $\begin{array}{l}\text { Transect } \\
\text { Number }\end{array}$ & Date & Station & River & $\mathbf{Q}$ & V & W Max & $\begin{array}{l}\text { Depth of } \\
\text { Sampling }\end{array}$ & H Max & Temp & EC & Turb & $\mathrm{pH}$ & TSS & $\begin{array}{c}\text { TSS } \\
\text { Fluxes }\end{array}$ \\
\hline & & & & $\mathrm{m}^{3} \cdot \mathrm{s}^{-1}$ & $\mathrm{~m} \cdot \mathrm{s}^{-1}$ & $\mathrm{~m}$ & $\mathrm{~m}$ & $\mathrm{~m}$ & ${ }^{\circ} \mathrm{C}$ & $\mu \mathrm{S} \cdot \mathrm{cm}^{-1}$ & NTU & & $\mathrm{mg} \cdot \mathrm{L}^{-1}$ & $\mathrm{~kg} \cdot \mathrm{s}^{-1}$ \\
\hline & 9-09-00 & $\begin{array}{c}\text { Puerto } \\
\text { Ayacucho }\end{array}$ & Orinoco & & 1.94 & & 0 & & 27.3 & 7.0 & 26.0 & 5.00 & 49.20 & \\
\hline $\mathrm{T} 1$ & $\begin{array}{c}\text { 10-09-00 } \\
" \\
"\end{array}$ & $\begin{array}{c}\text { Tamatama } \\
" \\
"\end{array}$ & $\begin{array}{c}\text { Orinoco } \\
" \prime \\
" \prime\end{array}$ & 2323 & 1.28 & 380 & $\begin{array}{c}0 \\
-2 \\
-4\end{array}$ & 5.20 & $\begin{array}{c}26.0 \\
" \\
"\end{array}$ & $\begin{array}{l}14.0 \\
14.0 \\
13.0\end{array}$ & $\begin{array}{l}22.0 \\
25.0 \\
30.0\end{array}$ & $\begin{array}{l}5.74 \\
5.78 \\
5.84\end{array}$ & $\begin{array}{l}34.40 \\
34.20\end{array}$ & 79.69 \\
\hline $\mathrm{T} 2$ & $10-09-00$ & $\begin{array}{l}\text { Downstream } \\
\text { bifurcation }\end{array}$ & Orinoco & 1343 & 1.11 & 270 & 0 & 5.80 & 26.5 & 15.0 & 24.0 & 5.70 & 32.00 & 42.99 \\
\hline $\mathrm{T} 3$ & $\begin{array}{c}\text { 10-09-00 } \\
" \\
"\end{array}$ & $\begin{array}{c}\text { Bifurcation } \\
\quad " \\
"\end{array}$ & $\begin{array}{c}\text { Casiquiare } \\
" \\
"\end{array}$ & 720 & 1.39 & 88 & $\begin{array}{c}0 \\
-3 \\
-6\end{array}$ & 7.30 & 26.0 & 14.0 & $\begin{array}{l}18.0 \\
30.0 \\
34.0\end{array}$ & 5.87 & $\begin{array}{l}43.60 \\
44.40\end{array}$ & 31.66 \\
\hline $\mathrm{T} 4$ & $\begin{array}{c}\text { 11-09-00 } \\
" \\
"\end{array}$ & $\begin{array}{c}\text { Mouth } \\
\text { " } \\
\text { " }\end{array}$ & $\begin{array}{c}\text { Casiquiare } \\
" 1 \\
"\end{array}$ & 5438 & 1.39 & 320 & $\begin{array}{c}0 \\
-6 \\
-12\end{array}$ & 14.10 & 26.7 & 7.0 & $\begin{array}{l}7.9 \\
7.0 \\
7.9\end{array}$ & 4.20 & $\begin{array}{c}8.00 \\
10.00 \\
9.00\end{array}$ & 48.94 \\
\hline T5 & $11-09-00$ & Confluence & Guainia & 2573 & 0.83 & 380 & 0 & 11.30 & 26.8 & 14.0 & 0.4 & 3.73 & 0.20 & 0.51 \\
\hline T6 & $11-09-00$ & San Carlos & Negro & 8034 & 1.19 & 600 & 0 & 14.30 & 26.9 & 9.0 & 1.5 & 3.20 & 5.60 & 44.99 \\
\hline T7 & $12-09-00$ & San Gabriel & Negro & 6878 & & & 0 & & 28.0 & 10.0 & 0.9 & 3.48 & 3.40 & \\
\hline
\end{tabular}




\subsection{Morphology Features and Hydro-Sedimentary Budget at the Bifurcation}

While the Orinoco River has a width of $380 \mathrm{~m}$ and $270 \mathrm{~m}$, respectively, at T1 and T2 (see Figure 6), before and after the bifurcation, the width of the Casiquiare Channel is smaller $(88 \mathrm{~m})$ and has a greater depth $(7.30 \mathrm{~m})$ than the Orinoco River $(5.20 \mathrm{~m})$. Flow velocity increases slightly from $1.28 \mathrm{~m} \cdot \mathrm{s}^{-1}$ in the Orinoco River (upstream) to $1.39 \mathrm{~m} \cdot \mathrm{s}^{-1}$ at the entrance of the Casiquiare (Table 1). The section at the entrance of the Casiquiare corresponds to about $28.5 \%$ of the section of the Orinoco before the bifurcation (Figure 6). The water balance is nearly $90 \%$ complete. Indeed, the sum of the flows at the Orinoco downstream of the bifurcation $\left(1343 \mathrm{~m}^{3} \cdot \mathrm{s}^{-1}\right)$ and the one at the entrance to the Casiquiare $\left(720 \mathrm{~m}^{3} \cdot \mathrm{s}^{-1}\right)$ is $2063 \mathrm{~m}^{3} \cdot \mathrm{s}^{-1}$ instead of $2324 \mathrm{~m}^{3} \cdot \mathrm{s}^{-1}$ for the Orinoco upstream of the bifurcation. It is possible that this inaccuracy is due to the flow measurement protocol. At the time of the study, the Casiquiare diverts about $30 \%$ of the flow of the Upper Orinoco River.

According to the annual averages calculated over the period 1970-1975, the bifurcation with a discharge of $320 \mathrm{~m}^{3} \cdot \mathrm{s}^{-1}$ diverts $25 \%$ of the flow from the Upper Orinoco [11]. Ron et al. [27] report that the minimum and maximum flows at the entrance to the Casiquiare, 127 and $680 \mathrm{~m}^{3} \cdot \mathrm{s}^{-1}$ respectively, maintain the same proportion between $22 \%$ and $25 \%$ of the flows in the Upper Orinoco River. These two rivers obviously have the same hydrological behavior with flow differences by a factor of 5 between rising and falling stages.

With regard to the physico-chemical data, we obtained $\mathrm{pH}$, electrical conductivity, and turbidity values of the Orinoco water, respectively in the order of $5.80,14 \mu \mathrm{S} \cdot \mathrm{cm}^{-1}$ at $25^{\circ} \mathrm{C}$ and $25 \mathrm{NTU}$ for TSS concentrations of $35 \mathrm{mg} \cdot \mathrm{L}^{-1}$ (Table 1). Note a higher value in TSS at the entrance to the Casiquiare $\left(44 \mathrm{mg} \cdot \mathrm{L}^{-1}\right)$ probably due to the increase in velocities, which results in a resuspension of particulate matter. In terms of sediment fluxes, the bifurcation balance closed to nearly $94 \%$. Indeed, the sum of the sediment flows of the Orinoco downstream of bifurcation and the one at the entrance of Casiquiare is $75 \mathrm{~kg} \cdot \mathrm{s}^{-1}$, very close to $80 \mathrm{~kg} \cdot \mathrm{s}^{-1}$ for the Orinoco upstream of the bifurcation. A report of the field work made in December 2001 [2] mentioned TSS concentrations around 20-25 mg. $\mathrm{L}^{-1}$, composed of $20 \%$ or $5 \mathrm{mg} \cdot \mathrm{L}^{-1}$ of sand $\left(>62 \mu \mathrm{m}\right.$ ) and $80 \%$ or $15-20 \mathrm{mg} \cdot \mathrm{L}^{-1}$ of fine TSS (between 62 and $0.45 \mu \mathrm{m}$ ).

\subsection{Morphology Features and Hydro-Sedimentary Budget at the Confluence}

At the confluence with the Guainia, the Casiquiare Channel presents widths, maximum depths, flow velocities, and discharges of $320 \mathrm{~m}, 14.10 \mathrm{~m}, 1.39 \mathrm{~m} \cdot \mathrm{s}^{-1}$, and $5439 \mathrm{~m}^{3} \cdot \mathrm{s}^{-1}$, respectively, compared to $380 \mathrm{~m}, 11.3 \mathrm{~m}, 0.83 \mathrm{~m} \cdot \mathrm{s}^{-1}$, and $2573 \mathrm{~m}^{3} \cdot \mathrm{s}^{-1}$ for the Guainia River, and $600 \mathrm{~m}, 14.30 \mathrm{~m}, 1.19 \mathrm{~m} \cdot \mathrm{s}^{-1}$, and $8034 \mathrm{~m}^{3} \cdot \mathrm{s}^{-1}$ for the Negro River just after the confluence (Table 1).

It should be noted that the measurements carried out in September 1970 yielded similar results [28]. At the bifurcation they reported $2430 \mathrm{~m}^{3} \cdot \mathrm{s}^{-1}$ for the Orinoco and $646 \mathrm{~m}^{3} \cdot \mathrm{s}^{-1}$ at the entrance of the Casiquiare. At the outlet, they measured $5440 \mathrm{~m}^{3} \cdot \mathrm{s}^{-1}$ at the Casiquiare and $3336 \mathrm{~m}^{3} \cdot \mathrm{s}^{-1}$ at Guainia. The mean flow discharge is about $2800 \mathrm{~m}^{3} \cdot \mathrm{s}^{-1}$ according to water levels recorded during the period 1970-1975 [2]. Using sixteen years of available discharge data during the period 1970-1986 (from the GRDC website), the hydrographs in Figure 1C were constructed, which illustrates comparatively the monthly variations of: (i) the Orinoco River discharge in Tamatama, (ii) the Casiquiare in its mouth downstream of Tamatama and (iii) in its mouth at the Solano hydrometric station. These last two hydrographs provide information on the extent of the contributions of the tributaries of the left bank of the Casiquiare.

At their confluence, Casiquiare and Guainia have morphologically similar sections (Figure 6). The flow of Casiquiare is two times higher than the one of the Guainia, mainly due to its 1.67 times higher flow velocity compared to that of the Guainia. The water balance is nearly $100 \%$ complete. Indeed, the sum of the flows measured at the outlet of the Casiquiare and at Guainia is $8011 \mathrm{~m}^{3} \cdot \mathrm{s}^{-1}$, compared to $8034 \mathrm{~m}^{3} \cdot \mathrm{s}^{-1}$ for the newly formed Negro River (see T6 in Figure 3B).

With regard to physical-chemical data, the $\mathrm{pH}$, electrical conductivity, turbidity, and TSS concentrations of the three confluence points are respectively: $3.73 ; 14 \mu \mathrm{S} \cdot \mathrm{cm}^{-1} ; 0.4 \mathrm{NTU} ; 0.2 \mathrm{mg} \cdot \mathrm{L}^{-1}$ 
for Guainia, $4.2 ; 7 \mu \mathrm{S} \cdot \mathrm{cm}^{-1} ; 7.6 \mathrm{NTU} ; 9 \mathrm{mg} \cdot \mathrm{L}^{-1}$ for Casiquiare and $3.9 ; 9 \mu \mathrm{S} \cdot \mathrm{cm}^{-1} ; 1.5 \mathrm{NTU} ; 5.6 \mathrm{mg} \cdot \mathrm{L}^{-1}$ for Negro, values similar to those found by Vegas et al. [29].

The electrical conductivity of Guainia River is twice as high as Casiquiare, probably due to a high presence of organic anions from humic and fulvic forest acids, which make them more acidic. Indeed, the black waters of the Guainia River, typical of "black water rivers", have just crossed a huge forest plain and are therefore much depleted of TSS compared to those of the Casiquiare, part of which comes from the loaded TSS waters of the Upper Orinoco.

The balance of sedimentary flows at the confluence is nearly $91 \%$ complete. Indeed, the sum of the flows from the Casiquiare and Guainia is $49.5 \mathrm{~kg} \cdot \mathrm{s}^{-1}$ instead of $45 \mathrm{~kg} \cdot \mathrm{s}^{-1}$, for Negro River in San Carlos station, just downstream of the confluence (see T6 in Figure 3B). Given the approximations on the flow calculations obtained from the adopted summary and simplified protocol, both from the point of view of flow measurement and from that of the calculations of the average concentrations of TSS, it is reasonable to assume that the law of conservation of mass is respected, both at the bifurcation and at the confluence.

\subsection{Global Budget and Functioning of the Casiquiare Hydraulic Complex}

The flow area of the channel at the outlet is 7.5 times larger than the one at the inlet, due to maximum depths and widths which are, respectively, 2 and 3.6 times greater. However, the flow velocity remains constant along the channel $\left(1.39 \mathrm{~m} \cdot \mathrm{s}^{-1}\right)$. These flow velocities are higher than those of the Orinoco upstream and downstream of the bifurcation $\left(1.28\right.$ and $\left.1.11 \mathrm{~m} \cdot \mathrm{s}^{-1}\right)$, and that those of the Guainia $\left(0.83 \mathrm{~m} \cdot \mathrm{s}^{-1}\right)$ and of the Negro River $\left(1.19 \mathrm{~m} \cdot \mathrm{s}^{-1}\right)$.

These higher Casiquiare flow velocities would come from both its elevation difference and the hydrological thrust from about 100 tributaries, mainly on the left bank, which input a total flow of 4720 $\mathrm{m}^{3} \cdot \mathrm{s}^{-1}$, i.e., 6.6 times higher than those at the entrance to the channel.

The flow discharge at the outlet is 7.5 larger than at the entrance, but its sedimentary fluxes are only 1.5 times higher, due to TSS concentrations 4.9 times lower at the end of the channel. The travel time of the waters of the Casiquiare, from its entry to its exit, is about 3 days during the rising stage of the hydrograph. Eight thresholds define its course and make it difficult to navigate in the falling stage, when many rocks are exposed at the surface of the water.

The values of turbidity, electrical conductivity, and pH decreased from 24 to $7.6 \mathrm{NTU} ; 14$ to 7 $\mu \mathrm{S} \cdot \mathrm{cm}^{-1}$ and 5.87 to 4.2 , respectively, from the inlet to the outlet. This longitudinal variability on $\mathrm{pH}$ and EC had already been highlighted by Edwards and Thornes [14]. Thus, the white waters at the entrance of the Casiquiare, which correspond to those of the Upper Orinoco, loaded with TSS, acquire, during their travel, more acidic pHs, turbidity, and lower conductivity, due to lateral inputs that have drained the forest cover and swampy plains on its left bank. In these ecosystems, there is little erosion due to lack of relief and slow runoff allows water to soak up dissolved organic matter. A progressive dilution of the waters of the Casiquiare then gives it a facies more and more similar to that of the "black rivers".

Figure 7 presents a schematic summary of the main parameters measured in the fluvial system. It represents the first model of the hydro-sedimentary behavior of the Casiquiare Channel with a distribution of morpho-hydrodynamic parameters in the three sections of its bifurcation and the three sections of its confluence.

Lateral sediment fluxes have been obtained from mass conservation principles. The TSS flux is equal to $17 \mathrm{~kg} \cdot \mathrm{s}^{-1}$ and the corresponding mean concentration is $3.6 \mathrm{mg} \cdot \mathrm{L}^{-1}$ (Figure $7 \mathrm{C}$ ). Similarly, the electrical conductivity, $\mathrm{pH}$, and turbidity of lateral inputs are equal to $7.15 \mu \mathrm{S} \cdot \mathrm{cm}^{-1}, 3.42$, and $4.4 \mathrm{NTU}$ (Figure 7B). These values are typical of the "black water" rivers in the Amazon basin.

A relationship between the TSS $\left(\mathrm{mg} \cdot \mathrm{L}^{-1}\right)$ and the turbidity (NTU) was obtained from the measurements in the Casiquiare Channel hydrological complex (Figure 8):

$$
\text { TSS }=1.4975 \times \text { Turb }+0.6206
$$




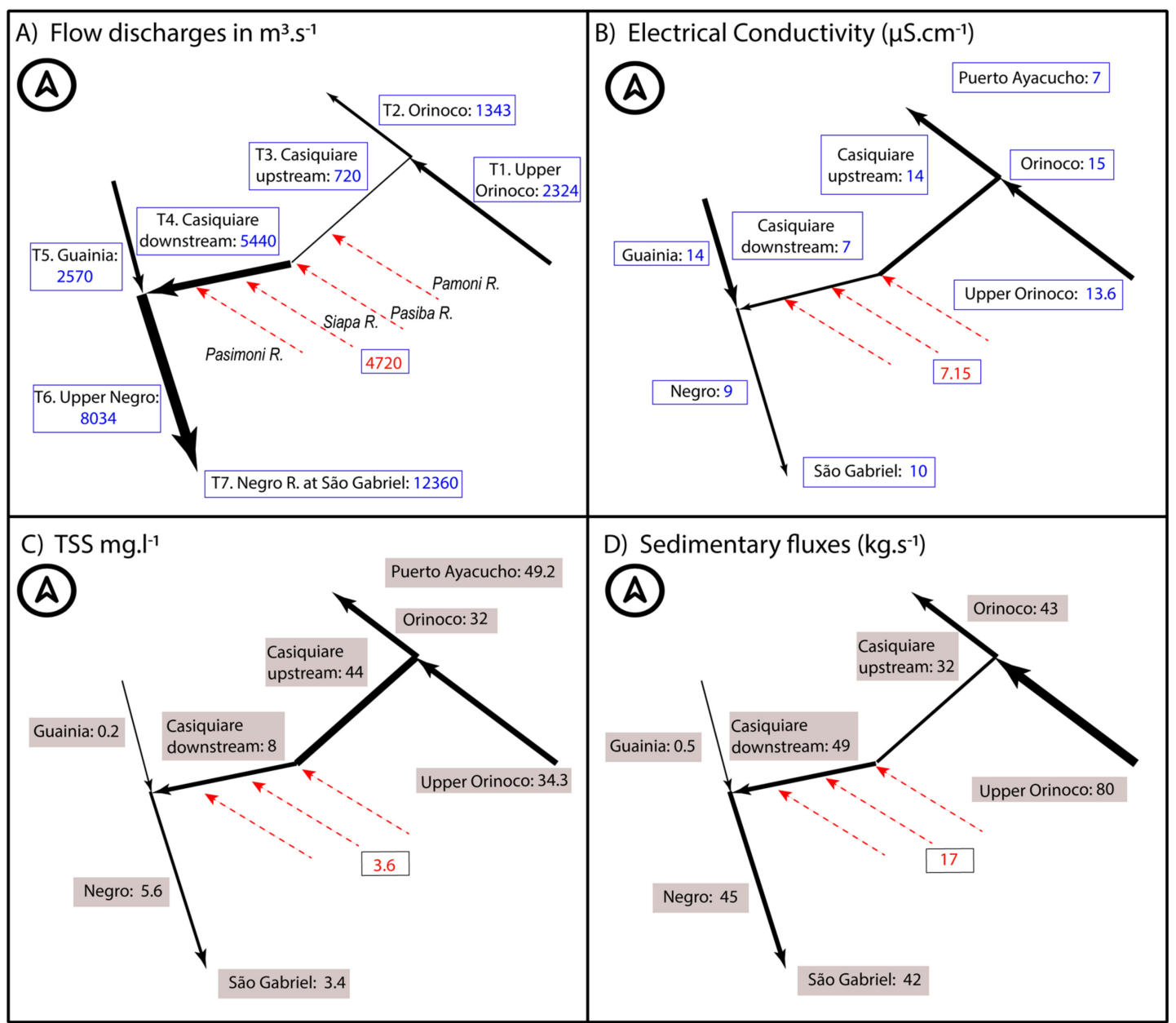

Figure 7. Schematic diagrams of the main morpho-dynamic and physico-chemical parameters measured in the Casiquiare hydrological complex from 9 to 12 September 2000. Numbers inside rectangles indicate flow discharges (Chart A), electrical conductivity (Chart B), suspended sediment concentrations (Chart C) and sediment fluxes (Chart $\mathbf{D})$.

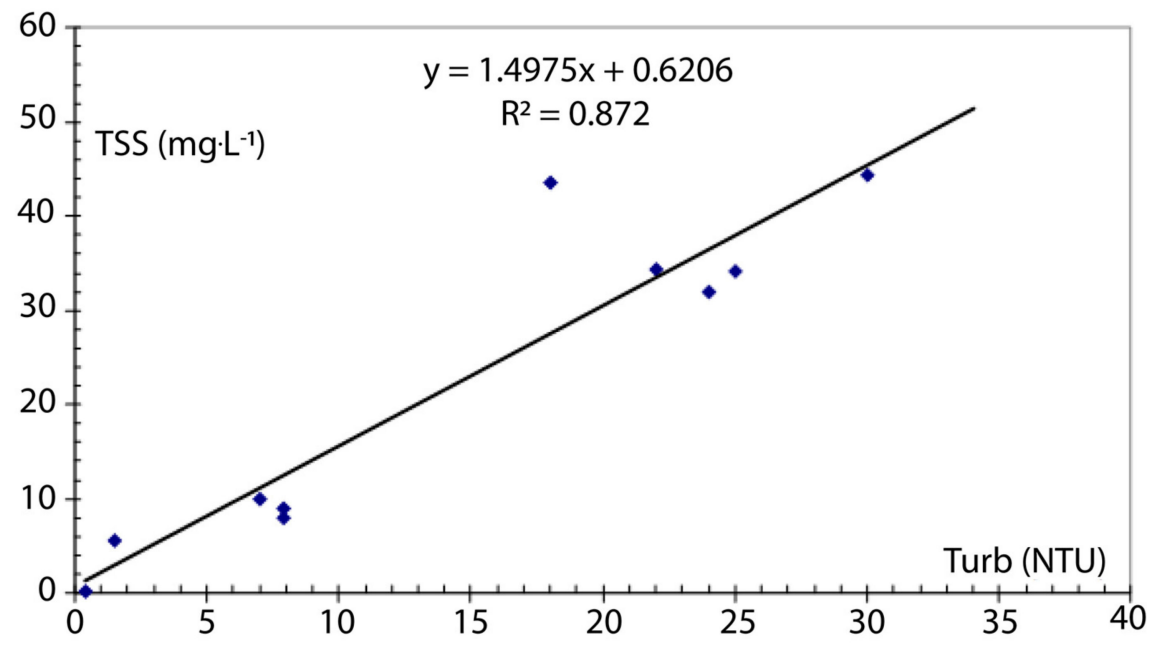

Figure 8. Relation between TSS $\left(\mathrm{mg} \cdot \mathrm{L}^{-1}\right)$ and turbidity (NTU) for the Casiquiare Channel.

It is worth noting that the interannual discharge of the Casiquiare bifurcation $\left(320 \mathrm{~m}^{3} \cdot \mathrm{s}^{-1}\right)$ corresponds to only $0.85 \%$ of the interannual discharge of the Orinoco at its delta, estimated at 37,600 $\mathrm{m}^{3} \cdot \mathrm{s}^{-1}$ [30-32]. In its mouth, the Amazon River presents an interannual discharge of $209,000 \mathrm{~m}^{3} \cdot \mathrm{s}^{-1}$ [33], 
of which $0.16 \%$ comes from the Upper basin of the Orinoco, and not $1.50 \%$ as reported by some authors such as Palacios [34], who takes into account the Casiquiare outlet discharge, instead of the inlet discharge at its bifurcation.

\section{The Problem of Tracing the Boundaries of the Watershed}

Tracing the boundaries between the watersheds of the Casiquiare and Upper Orinoco is an insoluble problem with the concepts of classical hydrology, since depending on the season, $20 \%$ to $30 \%$ of the waters of the Orinoco above the bifurcation flows into the Casiquiare. Thus, the Upper part of the Orinoco watershed feeds two basins and it is a kind of diffuse area which is not well defined.

At its bifurcation and confluence with the Negro River, the problem arises because fuzzy boundaries cross the marshy plains characterized by shallow lagoons and flooded forests under which superficial two-way laminar-flow runs according to the seasons and to the water levels of the rivers they connect. In addition to this, there are small secondary canals connecting the Orinoco to the Casiquiare and the latter with the Guainia River, mentioned by Georgescu [8], Carreteiro [35], and CAF [36]. These features are found in the depressions and vast plains of major river basins, such as the Congo [37]. Another peculiarity of the Casiquiare watershed is that it is limited almost exclusively to the north-west by its own river course. Indeed, the tributaries of its right bank are small streams, very few in number, whose drained areas are negligible compared to that of the whole basin.

Lewis and Weibezahn [38], Lewis and Saunders [39], Paolini [40], and Brown et al. [41] present acceptable boundaries between the two largest basins on the continent, although the ambiguity of the surface area of the Upper Orinoco River that feeds both this river and the Casiquiare is not mentioned.

According to Ron et al. [27], the area sensu stricto (s.s.) of the Casiquiare watershed, i.e., the area whose rainwater flows directly and solely towards the Casiquiare Channel, is about $33,000 \mathrm{~km}^{2}$, with an average flow rate at its outlet of $2790 \mathrm{~m}^{3} \cdot \mathrm{s}^{-1}$ [36] or $2100 \mathrm{~m}^{3} \cdot \mathrm{s}^{-1}$ [42]. According to the same author, the area of the Upper Orinoco River above the bifurcation is $37,870 \mathrm{~km}^{2}$. However, in this study a morphometric analysis using the Fluvial Corridor Toolbox and the DEM SRTM at $30 \mathrm{~m}$ showed that the area of the Upper Orinoco River Basin presents a contributing area above the bifurcation of 40,110 $\mathrm{km}^{2}$, coinciding quite well with the $40,000 \mathrm{~km}^{2}$ estimate made by Stokes et al. [22]. Likewise, for the Casiquiare Channel basin a contributing area of $42,810 \mathrm{~km}^{2}$ was estimated (Figure 9). Since it supplies both the Orinoco downstream of the bifurcation and the Casiquiare (in the order of $25 \%$ of its drainage water), it can be deduced that a total area of $82,920 \mathrm{~km}^{2}$ contributes to the Casiquiare water supply.

For this reason, the specific flow rate of the Casiquiare basin cannot be calculated, because its catchment is composed of two parts. The first one $\left(42,810 \mathrm{~km}^{2}\right)$ flows directly to the Casiquiare Channel (it is the sensu stricto (s.s.) watershed of the Casiquiare Channel) and the second one $\left(40,110 \mathrm{~km}^{2}\right)$ flows at the same time to the Orinoco and Casiquiare. That means that the Casiquiare basin is delimited by both a typical watershed line (surrounding an area of $42,810 \mathrm{~km}^{2}$ ) and by an unusual watershed area of $40,110 \mathrm{~km}^{2}$ (which corresponds to the Upper Orinoco catchment) shared by the Orinoco and Amazon basins (Figure 9). The addition of these two contours delimits the surface area of the basin sensu lato (s.l.) of the Casiquiare, including the famous shared surface of the Upper Orinoco which does not only flow to the Casiquiare.

Figure 9 also compares the calculated slopes with the DEM SRTM (pixel $\sim 30 \mathrm{~m}$ ) for the Casiquiare Channel with respect to the slope calculated locally by USACE [9], small differences can be observed ( 8.5 versus $6 \mathrm{~cm} \cdot \mathrm{km}^{-1}$ ). These small differences can be explained as a result of uncertainties in local sampling (elevations using barometric measurements surveyed by the USACE), as well as by the low spatial resolution of the DEM used (in the current study). While terrain elevation models are very helpful for direct quantification of slope in channels, the accuracy of these analyses is a function of the spatial resolution of the DEM, the data acquisition system, the smoothing algorithms, as well as the methodology used for channel profile extraction. Currently, with the use of DEMs derived from Light Detection and Ranging (LIDAR) data, it is possible to obtain accurate slope estimates over relatively short distances. However, considerable shortening of channels and excessively steep 
slope estimates have also been documented when using a coarse data system such as ASTER GDEM $30 \mathrm{~m}$ or similar [43]. When evaluating the profiles of both channels a very subtle slope break can be observed that effectively shows the occurrence of the bifurcation in the main channel from the Upper Orinoco to the Casiquiare Channel. However, in order to better understand this hydrological phenomenon in the future it will be crucial to acquire and analyze new field measurements with the most recent technologies.

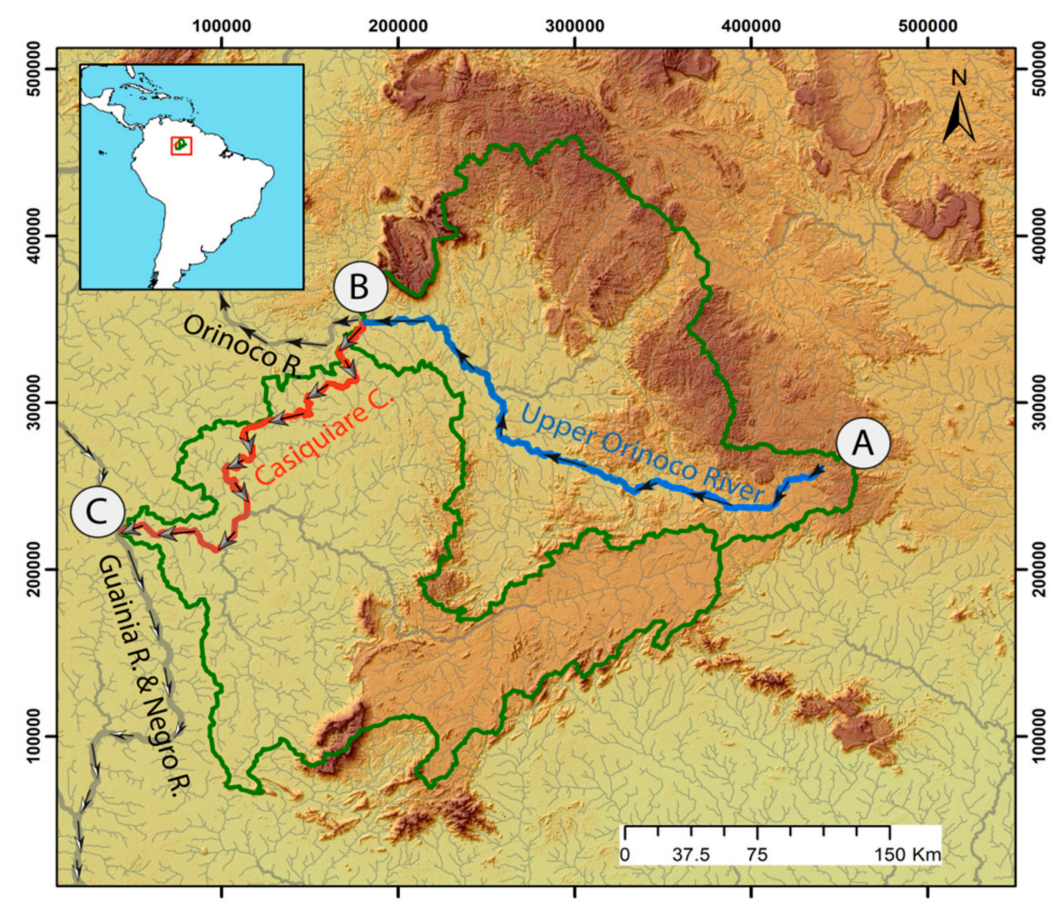

Synoptic diagram of the elevation, slope and contribution area of each basin

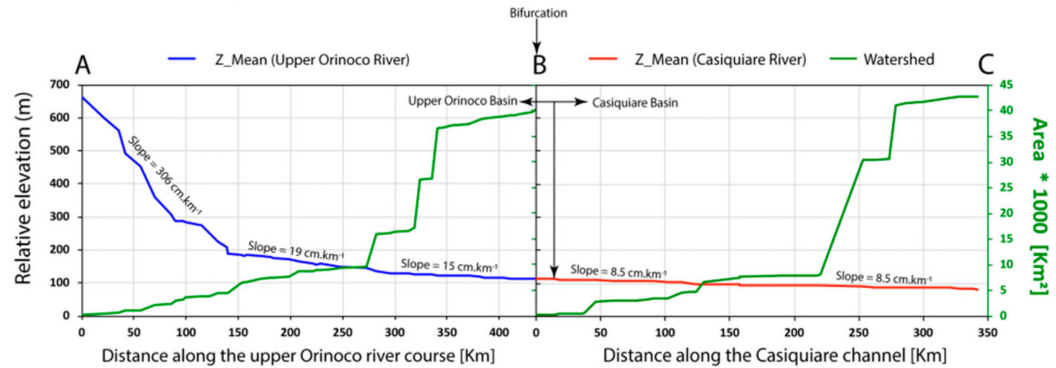

Figure 9. Boundaries of the Casiquiare s.s. catchment and Upper Orinoco catchment (green lines). The blue line delineates the Upper Orinoco River and the red line the Casiquiare Channel with a total length of $\sim 350 \mathrm{~km}$. A synoptic diagram highlights the contributing area in each basin, as well as the elevation and slope of each of the two rivers.

Depending on the season, 20 to $30 \%$ of the water from the Upper Orinoco upstream of Tamatama flows into the Casiquiare, which means that the same percentage of rainfall on the part of the catchment area upstream of the bifurcation is discharged through this channel, while the rest (70-80\%) flows into the Orinoco River. Thus, it can be assumed that the same portion of a watershed feeds two rivers unevenly in the proportions previously stated.

This natural situation is unique in the world in terms of: (i) its location at the headwaters of a watershed, (ii) the areas of the sharing basin, (iii) discharge involved, (iv) for flows in only one direction, (v) the length of the channel, and (vi) the distance between the mouth of the Amazon and Orinoco rivers that are fed by the Upper Orinoco River. 


\section{An Ecological Connectivity Between the Orinoco and Amazon Basins}

The Casiquiare links two basins characterized by different geomorphologic and geochemical conditions. The upper basin of the Orinoco River is a typical mountain relief of the tropics, covered with dense vegetation, containing mostly clear-water streams with slightly acid $\mathrm{pH}$ and moderate concentrations of dissolved organic and inorganic substances [44]. On the other hand, the upper basin of the Negro River, at lower elevations and covered in tropical forests, with areas of savanna occurring in upland regions, is dominated by 'blackwater streams' with high transparency but strong staining by tannins and other organic compounds leached from vegetation, extremely low $\mathrm{pH}$, negligible amounts of solutes, and substrates of fine quartz sand [42].

Above the Casiquiare bifurcation, the Orinoco is a white-water stream with a common light brown color, so the Casiquiare begins its course with the same water conditions. However, during its $\sim 350 \mathrm{~km}$ long-course, along its left bank, the Casiquiare receives the flows of many predominant black-water streams, like the Pamoni, Pasiba, Siapa, and Pasimoni rivers, carrying clear-acid-swamp water due to the high content of dissolved-organic humic acids. Thus, the Casiquiare suffers a gradual transition in the color of the river until its discharge into the Negro River, representing a hydrochemical gradient between white waters at its origin and black waters at its mouth.

The Casiquiare influences the migration of aquatic organisms between the Orinoco and Amazon basins and seems to function as an interbasin dispersal corridor for fish, but the effectiveness of this connection is mitigated by the strong physical-chemical and ecological gradient that spans its length. Winemiller and Willis [45] concluded that the degree to which the river serves as a dispersal corridor or barrier is variable and depends on the physiological and ecological tolerances of individual species.

\section{Other River Captures}

Very few natural hydrological captures exist worldwide that present some similarities with the Casiquiare. Without being exhaustive, it can be mentioned the Echimamish River in Canada, which connects the Hayes and Nelson Rivers flowing into Hudson Bay [46]. In this small connection that crosses a marshy region, the weak currents in the Echimamish River are reversed according to the water levels of the two connected rivers. This is the case for most of the world's bifurcations, many of which are intermittent and others are inside the same river basin. Another analogue ongoing river capture is the Selinda spillway of Southern Africa, which diverts water from the Okavango towards Kwando and Zambezi rivers, probably by overflow during the rising stage of Okavango River [47].

It seems that the only other current bifurcation similar to the Casiquiare is the Tarendö-elf canal in Sweden, which diverts $80 \mathrm{~m}^{3} \cdot \mathrm{s}^{-1}$ of the flows of the Torne River towards the Kalix River, along a winding path of $52 \mathrm{~km}$ in a marshy terrain. Its origin would also come from an overflow of the Torne River, which would be the cause of its partial capture. Two hundred $\mathrm{km}$ downstream of this junction, the Torne and Kalix rivers flow into the Bay of Bothnia in the Baltic sea, with only $20 \mathrm{~km}$ distance between its rivers mouths [48]. However, the hydrological singularity of the Casiquiare is unique in its size. It is the only permanent and one-way bifurcation that extends for more than $300 \mathrm{~km}$ long with flow discharges varying between several hundred and a few thousand $\mathrm{m}^{3} \cdot \mathrm{s}^{-1}$, it also connect two neighboring basins with very distant deltas separated about $1500 \mathrm{~km}$ apart.

\section{Conclusions}

The Casiquiare Channel is a bifurcation flowing all year in the same direction from the Orinoco basin to the Amazon basin. Throughout its course, this natural channel undergoes significant morphological, hydrological, and bio-geochemical variations, whose most visible witnesses are the increase in width ( 3 to 4 times), flow (7 to 9 times), and its change in water color (white to black), under the influence of tributaries coming from vast forest plains. For this reason, it can be called a chameleon channel. 
Studies made by other researchers [2,9] were interested more in the hydrology and hydraulics of the system, than in the sediment balance. Water and sediment budget is important in the Casiquiare system because of future plans for establishing a South American river integration system through the Orinoco, Casiquiare, Negro, Amazon, Paraguay, Parana, and Río de la Plata Rivers [36]. In this paper, a hydro-sedimentary balance of the Casiquiare fluvial system has been presented based on field data collected in September 2000.

At the beginning of the falling stage of the hydrograph, the flow at the bifurcation inlet channel corresponds to about $13 \%$ of those of the outlet flows. The latter, in the order of $5500 \mathrm{~m}^{3} \cdot \mathrm{s}^{-1}$ or an annual average of $2800 \mathrm{~m}^{3} \cdot \mathrm{s}^{-1}$, are respectively 7 to 9 times higher than those at the inlet. The relatively high average slope $\left(6 \mathrm{~cm} \cdot \mathrm{km}^{-1}\right)$ of the channel leads to relatively high velocities of up to $1.4 \mathrm{~m} \cdot \mathrm{s}^{-1}$ during rising stage. The natural slope and these velocities produce a river channel without many meanders and its operating dynamics should be more one of erosion-transport rather than sedimentation.

The geochemical facies of the waters range from "white water" $(\mathrm{pH}=5.87)$ loaded in suspended sediment in the order of $44 \mathrm{mg} \cdot \mathrm{L}^{-1}$, coming from the relief belt that delimits the Upper Orinoco basin with that of the Amazon, to a facies characteristic of the "black rivers", more acidic $(\mathrm{pH}=4.20)$ and less loaded by sediment $\left(8 \mathrm{mg} \cdot \mathrm{L}^{-1}\right)$ and dissolved mineral matter. This is due to significant dilution by numerous inputs from left bank tributaries crossing vast forest plains. Additionally, the electric conductivity changed from 14 to $7 \mu \mathrm{S} \cdot \mathrm{cm}^{-1}$. The longitudinal physical-chemical gradients clearly illustrate the evolution of this chameleon channel where the outlet waters are mixed by lateral inflows (tributaries), which are respectively 6 to 8 times higher than those at the inlet, depending on whether one is in rising stage or whether one considers the average module.

The surface of the Casiquiare catchment area sensu lato (s.1.) is about $82,920 \mathrm{~km}^{2}$, and approximately half of it feeds two rivers at the same time, the Orinoco and Casiquiare. Thus it can be considered that only about $1 / 4$ of the drainage area of the Upper Orinoco $\left(40,110 \mathrm{~km}^{2}\right)$ is flowing to the Casiquiare. It is an unusual watershed area shared between the Orinoco and Amazon basins. In total, $0.9 \%$ of the Orinoco's average annual flow at its ocean mouth is diverted by the Casiquiare Channel to the Amazon. Through this channel, the Upper Orinoco River contributes 0.16\% of the Amazon's average annual flow at its mouth.

Author Contributions: Conceptualization: A.L., J.L.L. and P.G.; Methodology: A.L., J.L.L. and S.Y.; Software: S.Y.; Validation: A.L. and P.G.; Formal analysis: A.L., J.L.L. and S.Y.; Investigation: A.L., J.L.L. and S.Y.; Data curation: A.L., S.Y. and P.G.; Writing—original draft preparation: A.L., J.L.L., P.G. and S.Y.; Writing-review and editing: A.L., J.L.L. and S.Y.; Project administration: A.L. and P.G.; Funding acquisition: P.G.

Funding: This research received no external funding.

Acknowledgments: This study has been carried out under the sponsorship of the Simón Bolívar University (USB, Venezuela) and the University of Brasilia (UnB, Brazil) with the assistance of the Venezuelan and Brazilian armed forces and the Institute of Research for Development (IRD, France), during the international fluvial expedition 'Humboldt-Amazonia 2000'.

Conflicts of Interest: The authors declare no conflict of interest.

\section{References}

1. Laraque, A.; Castellanos, B.; Steiger, J.; Lopez, J.L.; Pandi, A.; Rodriguez, M.; Rosales, J.; Adèle, G.; Perez, J.; Lagane, C. A comparison of the suspended and dissolved matter dynamics of two large inter-tropical rivers draining into the Atlantic Ocean: The Congo and the Orinoco. Hydrol. Process. 2013, 27, 2153-2170. [CrossRef]

2. Pérez, H.D. Mediciones Hidrológicas en el Sector Alto Orinoco-Caño Casiquiare; MARNR: Caracas, Venezuela, 2002.

3. The Global Runoff Data Centre GRDC-The World-Wide Repository of River Discharge Data and Associated Metadata. Available online: https://www.bafg.de/GRDC/EN/01_GRDC/grdcnode.html (accessed on 15 March 2019).

4. Sternberg O'Reilly, H. The Amazon River of Brazil; Geographische Zeitschrift, Beihefte Erdk. Wissen 40; Franz Steiner: Wiesbaden, Germany, 1975; p. XII+ 74. 
5. Goodland, R.; Irwin, H. A Selva Amazônica: Do Inferno Verde ao Deserto Vermelho; Universidade de Sao Paulo: São Paulo, Brazil, 1976.

6. Von Humboldt, A. Voyage Dans Les Régions Equinoxiales du Nouveau Continent; Tome II; N. Maze: Paris, France, 1819; Available online: http://gallica.bnf.fr/ark:/12148/bpt6k61299w (accessed on 14 March 2018).

7. La Condamine, C.M. Relation Abrégé D'un Voyage Fait Dans L'amérique Méridionale; Académie des Sciences: Paris, France, 1981.

8. Georgescu, C.P. Los Ríos de la Integración Suramericana; USB: Caracas, Venezuela, 1984.

9. USACE (U.S. Army Corps of Engineers). Orinoco-Casiquiare-Negro Waterway. In Venezuela-Colombia-Brasil; USACE: Washington, DC, USA, 1943.

10. Georgescu, P.; Georgescu, C.P.; Laraque, A. Le Casiquiare ... un Fleuve qui Relie Deux Fleuves! Bulletin de la Société de Géographie; Société de Géographie: Paris, France, 2008.

11. Nordin, C.F.; Meade, R.H. The Amazon and the Orinoco. In McGraw-Hill Yearbook of Science E Technology; McGraw-Hill Inc.: New York, NY, USA, 1986; pp. 385-390.

12. Meade, R.H.; Koehnken, L. Distribution of the river dolphin, tonina "Inia geoffrensis", in the Orinoco River Basin of Venezuela and Colombia. Interciencia 1991, 16, 300-312.

13. Gessner, F. Ensayo de una comparación química entre el Río Amazonas, el Río Negro y el Río Orinoco. Acta Científica Venez. 1960, 11, 63-64.

14. Edwards, A.M.C.; Thornes, J.B. Observations on the dissolved solids of the Casiquiare and Upper Orinoco, April-June. Amazoniana 1968, 2, 245-256.

15. Edmond, J.; Palmer, M.; Measures, C.; Grant, B.; Stallard, R. The fluvial geochemistry and denudation rate of the Guayana Shield in Venezuela, Colombia and Brazil. Geochim. Cosmochim. Acta 1995, 59, 3301-3325. [CrossRef]

16. Sidder, G.B.; Mendoza, S.V. Geology of the Venezuelan Guayana Shield and Its Relation to the Entire Guayana Shield; USGS Open-File Rept; US Geological Survey: Reston, VA, USA, 1991; pp. 91-141.

17. Goldstein, R.J. Angelfish. Barron's; B.E.S. Publishing: Hauppauge, NY, USA, 2001; 96p.

18. Stern, K.M. Der Casiquiare-Kanal, einst und jetzt. Amazoniana 1970, 2, 401-416.

19. Vareschi, V. La Bifurcación del Orinoco: Observaciones Hidrográficas Ecológicas de la Expedición Conmemorativa de Humboldt del año 1958. Acta Científica Venez. 1963, 14, 9.

20. Besler, H. Beobachtungen zum Casiquiare-problem (Remarques sur le problème du Casiquiare). Erdkunde 1995, 49, 152-156. [CrossRef]

21. Grohmann, C.H. Tectonic Controls on the Capture of the Orinoco River and Formation of the Casiquiare Canal, Venezuela. Geol. Soc. Am. Abstr. Programs 2012, 44, 188.

22. Stokes, M.F.; Goldberg, S.L.; Taylor, J. Ongoing river capture in the Amazon. Geophys. Res. Lett. 2018. [CrossRef]

23. Stern, K.M. La Génesis del Casiquiare. Acta Científica Venez. 1954, 5, 52-53.

24. Subramanya, K. Flow in Open Channels, 3rd ed.; Tata McGraw-Hill Education: New York, NY, USA, 1982.

25. USGS. Shuttle Radar Topography Mission, 1 Arc Second Scene SRTM_u03_n008e004, Unfilled Unfinished 2.0, Global Land Cover Facility; University of Maryland: College Park, MD, USA, 2000.

26. Roux, C.; Alber, A.; Bertrand, M.; Vaudor, L.; Piégay, H. "Fluvial Corridor": A new ArcGIS toolbox package for multiscale riverscape exploration. Geomorphology 2015, 242, 29-37. [CrossRef]

27. Ron, E.; León, R.; Mejía, A.; Colmenares, G. Informe de Las Condiciones Hidráulicas del Caño Casiquiare; Revista El Agua: Caracas, Venezuela, 1982.

28. MOP. Mediciones en Ríos Grandes; Ministerio de Obras Públicas, División de Hidrología: Caracas, Venezuela, 1972.

29. Vegas, V.; Paolini, J.; Herrera, R. A physico-chemical survey of black water rivers from the Orinoco and the Amazon basins in Venezuela. Arch. Hydrobiol. 1988, 111, 491-506.

30. Cordoba, J.R. Caracterización del Funcionamiento Hidrológico e Hidráulico-Fluvial del Delta del Rio Orinoco. In PDVSA-Informe Desarrollo Armónico de Oriente DAO; FUNINDES, USB: Caracas, Venezuela, 1999.

31. Silva, G. La cuenca del rio Orinoco: Visión hidrográfica y balance hídrico. The Orinoco River Basin: Hydrographic view and its hydrological balance. Rev. Geogr. Venez. 2005, 46, 75-108.

32. Laraque, A.; Pouyaud, B.; Rocchia, R.; Robin, R.; Chaffaut, I.; Moutsambote, J.M.; Maziezoula, B.; Censier, C.; Albouy, Y.; Elenga, H.; et al. Origin and function of a closed depression in equatorial humid zones: The lake Tele in the north Congo. J. Hydrol. 1998, 207, 236-253. [CrossRef] 
33. Molinier, M.; Guyot, J.L.; Oliveira, E.; Guimarães, V. Les Régimes Hydrologiques de L'amazone et de Ses Affluents; IAHS: Paris, France, 1996.

34. Palacios, M.O. El Orinoco, Tercer río Del Mundo; Fundación Avensa y Fundación Terramar: Caracas, Venezuela, 1998.

35. Carreteiro, R.P. A Navegação na Amazônia; Editora Calderaro Ltda.: Manaus, Brazil, 1987; pp. $62-65$.

36. CAF. Los Ríos Nos Unen. Integración Fluvial Suramericana; Corporación Andina de Fomento: Caracas, Venezuela, 1998.

37. Laraque, A.; Georgescu, P.; Hernández, D.P. El canal del Casiquiare: Una singularidad hidrológica única en el mundo. In Proceedings of the XXII Congreso Latinoamericano de Hidráulica, Ciudad Guayana, Venezuela, 9-12 October 2006.

38. Lewis, W.M.; Weibezahn, F.H. The chemistry and phytoplankton of the Orinoco and Caroni rivers, Venezuela. Arch. Hydrobiol. 1981, 91, 521-528.

39. Lewis, W.M.; Saunders, J.F. Concentration and transport of dissolved and suspended substances in the Orinoco River. Biogeochemistry 1989, 7, 203-240. [CrossRef]

40. Paolini, J. Organic carbon in the Orinoco River (Venezuela). Verh. Internat Verein. Limnol. 1991, 24, $2077-2079$. [CrossRef]

41. Brown, E.; Edmond, J.; Raisbeck, G.; Bourlès, D.; Yiou, F.; Measures, C. Beryllium isotope geochemistry in tropical river basins. Geochim. Cosmochim. Acta 1992, 57, 1607-1624. [CrossRef]

42. Winemiller, K.; Lopez-Fernandez, H.; Taphorn, D.C.; Nico, L.G.; Duque, A.B. Fish assemblages of the Casiquiare River, a corridor and zoogeographical filter for dispersal between the Orinoco and Amazon basins. J. Biogeogr. 2008, 35, 1551-1563. [CrossRef]

43. Carretier, S.; Tolorza, V.; Regard, V.; Aguilar, G.; Bermúdez, M.A.; Martinod, J.; Guyot, J.L.; Hérail, G.; Riquelme, R. Review of erosion dynamics along the major NS climatic gradient in Chile and perspectives. Geomorphology 2018, 300, 45-68. [CrossRef]

44. Weibezahn, F.H.; Alvarez, H.; Lewis, W.M., Jr. (Eds.) The Orinoco River as an Ecosystem; EDELCA: Caracas, Venezuela, 1990.

45. Winemiller, K.; Willis, S.C. The Vaupes Arch and Casiquiare Canal: Barriers and Passages. In Historical Biogeography of Neotropical Freshwater Fishes; Albert, J.S., Reis, R., Eds.; The Regents of the University of California: Oakland, CA, USA, 2011.

46. McLeod, S.L. The Evolution of the Echimamish River: Northern Manitoba; FGS-Electronic Theses \& Dissertations (Public): Winnipeg, MB, Canada, 1975; Available online: http://hdl.handle.net/1993/6165 (accessed on 7 August 2019).

47. Gumbricht, T.; McCarthy, T.S.; Merry, C.L. The topography of the Okavango Delta, Botswana, and its tectonic and sedimentological implications. S. Afr. J. Geol. 2001, 104, 243-264. [CrossRef]

48. Siergieiev, D. Impact of Hydropower Regulation on River Water Geochemistry and Hyporheic Exchange. Ph.D. Thesis, Luleå Tekniska Universitet, Luleå, Sweden, 2013.

(C) 2019 by the authors. Licensee MDPI, Basel, Switzerland. This article is an open access article distributed under the terms and conditions of the Creative Commons Attribution (CC BY) license (http://creativecommons.org/licenses/by/4.0/). 